\title{
Choosing celebrity endorsers for advertising campaigns in cosmopolitan China: Does their ethnicity matter?
}

\author{
V. Apaolaza ${ }^{a *}$, P. Hartmann ${ }^{\text {a }}$, J. He ${ }^{b}$, J.M. Barrutiac and C. Echebarria ${ }^{c}$ \\ ${ }^{a}$ Faculty of Economics and Business Administration, University of the Basque Country UPV/EHU, Bilbao, Spain; \\ ${ }^{\mathrm{b}}$ School of Business, East China Normal University, Shanghai, PRC; \\ ${ }^{c}$ Institute of Applied Business Economics, University of the Basque Country UPV/EHU, Bilbao, Spain,
} Tel: (+34) 945014489

*To whom all correspondence should be addressed. vanessa.apaolaza@ehu.es

\begin{abstract}
This study asks if endorsers function as surrogates for country-of-origin, and if the effectiveness of the tactic varies with the perceived ethnicity (Western versus Chinese) of the celebrities. It finds no significant influence on the country-oforigin perception, brand attitudes or product quality evaluations in the reactions of 797 consumers in Shanghai to magazine advertisements featuring celebrities of Chinese vs. Western ethnicity. The lack of any significant effect of the ethnicity of celebrities on a brand's perceived country of origin precludes country image having any effect on those variables for the case of the cosmopolitan Chinese consumer.
\end{abstract}

\section{Introduction}

This paper intended to study Shanghai consumers in order to get a good picture of their reactions toward celebrity endorsers in advertising. Considered as the "New York of China", Shanghai city is very open to the Western world and highly multi-cultural, a place where consumers are exposed to a large amount of advertising messages generated both by local and foreign companies. Thus, even though the forces of globalisation and the increasing presence of multinational firms in Shanghai may be leading it towards "Western-style values and gimmicks", daunting challenges face the international marketers who are "increasingly targeting such a diverse and complex market" (Simmons \& Schindler, 2003). In this cosmopolitan China, intensified competition among advertisers has resulted in celebrity endorsement becoming one of the prevalent strategies for creating positive associations in the minds of local consumers (Chan \& Zhang, 2007; Gan, 2006; Liu, Huang \& Minghua, 2007). Indeed, it is claimed by Gan (2006) to be one of the "most effective" advertising techniques in the worldwide Chinese marketplace, such success being attributable in his opinion to an increasingly consumerist society, in which it is considered a status symbol to possess an endorsed product.

The claimed benefits of celebrity endorsement include enhanced advertising recall, brand desirability, product glamour (Spielman, 1981), as well as heightened awareness of a company's advertising and positive feelings towards its brands (Solomon, 2002). Previous research has shown that celebrity endorsement is an effective strategy for gaining and holding attention (Atkin \& Block, 1983), which favorably influences brand attitudes, enhances the likelihood of purchase (Friedman \& Friedman, 1979), fosters brand loyalty, and positively influences word of-mouth communication (Bush, Martin \& Bush, 2004). This practice has in addition, a direct relation upon investment return, for it has been shown that the general public is willing to pay up to $20 \%$ more for one and the same article when it is presented by a celebrity (Rumschisky, 2010). Therefore, one of the key decisions that both foreign and local companies that wish to operate in Shanghai will have to make, concerns the most appropriate choice of celebrity for their products and brands.

The prominence of celebrity endorsers in advertising has given rise to several studies into celebrity-endorser effectiveness and consumer responses (e.g. Frieden, 1984; Goldsmith, Lafferty \& Newell, 2000; Kahle \& Homer, 1985; Kamins, 1990; Stafford, Stafford \& Day, 2002). Yet celebrity endorsement in international advertising contexts has not received much attention. For McCracken (1989), celebrity-endorsed advertising success depends on whether the celebrity endorser proves meaningful within a culture's consumer values and norms (Paek, 2005). For the Chinese market, one stream of the literature suggests that it is indicated to employ local celebrities because they will prove to be more congruent with the cultural values of Chinese consumers who, being generally fairly ethnocentric, will then be able to identify more with the famous person (Cui \& Yang, 2009; Frith, Cheng \& Shaw, 2004; Leach \& Liu, 1998). Using a local celebrity may be a way for a company to express adaptation to the local market and identification with the native culture and language.

Nevertheless, other authors point out that the use of local celebrities may suggest that the advertised product or brand is national, when what many companies in the cosmopolitan China are actually seeking to transmit is an international company image. Indeed, according to Zhuang et al. (2008), 
the more a brand which is in fact local is perceived to be of foreign origin, the greater the consumer preference for it will be. The literature further suggests that foreign and global brands make consumers members of a specific global segment (Alden, Steenkamp \&Batra, 1999), provide them with the psychological benefit of brand globalness (Steenkamp, Batra \& Alden, 2003), and make them feel part of something bigger (Holt, Quelch \& Taylor, 2004). Venkatesh and Swamy (1994) argued that consumers in developing economies such as China today want to be able to participate in the global consumer community, living in this "imagined world", in part, through access to products from all over the world. Bilingual naming of brands originating in China has indeed become an increasingly common strategy in Shanghai, precisely to confer a more cosmopolitan and global image (Zhang \& Schmitt, 2001, 2004).

A question of fundamental importance thus arises: will the advertising campaigns in this cosmopolitan China be more effective if the chosen 'faces' reflect the ethnic profile of the target market or a different (foreign and international) profile? This is, of course, a specific case of the general globalization-versus-localization argument, which has become the subject of intense interest among specialist academics and thoughtful practitioners (Cheong, Zheng \& Kim, 2011; Cui \& Yang, 2009; Gan, 2006; Hong, 1994; Morimoto \& La Ferle, 2008). In a context where celebrities are used as brand endorsers, our understanding is that companies that try to provide their products with a global international image might prefer to use foreign celebrities, while companies that desire to project a local image would possibly opt for choosing Chinese celebrities. It is intuitively logical to assume that brands endorsed by, for example, Western celebrities will be seen to be of foreign origin by Chinese consumers, and vice versa. In this regard, there is an important communicational element implicit in celebrity itself, comprising ethnic origin, which has not yet been studied in the literature. It is also of great importance to study this in markets such as Shanghai, where companies very often seriously discuss whether it is more appropriate to use foreign or local faces in their advertising.

We interpret a celebrity's ethnicity as a factor of significance because it transmits information to the consumer regarding the product or brand's place of provenance, thereby influencing (through this effect on the product or brand's perceived country of origin) consumer perceptions about product quality and their attitude towards the brand. Scores of studies have already documented the ways in which consumers use a brand's country of origin (COO) as a cue in inferring its quality and acceptability (Baughn \& Yaprak, 1993; Bilkey \& Nes, 1982).

Interpreting celebrity endorsers as cultural value representatives, this study asks if endorsers function as surrogates for country-of-origin, and whether the effectiveness of the tactic varies with the perceived ethnicity (Western versus Chinese) of the celebrities. Specifically, the aim is to analyze whether the ethnic origin (Western versus Chinese) of a celebrity used as brand image impacts on variables such as: "perception of the brand's country of origin", "perception of product quality", and "brand attitude" for the specific case of the global and cosmopolitan consumers of Shanghai city; this point has not, to date, been researched in the scientific literature.

\section{Theoretical background}

\section{The choice of celebrity according to congruence theory and the degree of consumer ethnocentrism}

According to congruence theory, the literature shows that some Western advertisers in Asian markets are prone to using endorsers who are themselves Asian (Cui \& Yang, 2009; Frith et al., 2004). Congruence theory (Newcomb, 1968) postulates that, in order to maintain cognitive harmony and symmetry, individuals tend to be more responsive to people who reflect their own beliefs and attitudes, and messages that are consistent with them. Glenn, Witmeyer and Stevenson (1977) argued that those who attempt to persuade others "select approaches consistent with their own past experiences within the cultures to which they belong ... in part, on the basis of their ability to handle a style congruent with the culture". Wang et al. (2000) express this phenomenon as a cultural match resulting from the congruence of an advertising appeal with consumers' self-schemata. In the context of international marketing, the inference is that marketers using a strategy in which identifiable 'faces' use the product or commend it by association, should localize their advertising strategies in other countries through the use of local celebrities, so as to make it easier for the target audience to identify with these human representatives of the advertised product or brand.

Indeed, the effect of not considering congruence may actually be reduced effectiveness or even perceived offensiveness in the foreign culture (Leach \& Liu, 1998). For example, a Toyota advertisement featuring Brad Pitt was banned in Malaysia for being an "insult to Asians" by promoting a Western ideal of male beauty (The Economist, 2012). Many international marketers have accordingly advocated the adaptation of advertising to include culturally relevant appeals that reflect local values (Chattaraman, Lennon \& Rudd, 2010; DeShields, Kara \& De los Santos, 1999; Ryu, Park \& Feick, 2006; Zhang \& Gelb, 1996).

In parallel with the rapid development of the Chinese economy, consumers have become more sophisticated, proud and confident about themselves and their own culture (Shen \& Guo, 2013). In response to this trend, major multinational brand advertisers have featured Chinese endorsers and users in their promotional campaigns. A recent study by Cui and Yang (2009) found that evaluations of a fictitious digital camera with an English brand name were more positive when the 'faces' were Chinese than when they reflected the country of origin of the product itself. This finding strongly supports the appropriateness of congruency theory as a basis for analysis of the effect of the perceived ethnicity of individuals featuring in international advertising. 
Other researchers have further concluded that this preference for local representatives of the brand is conditioned not only by the fact that the public might sense a greater degree of identification with the famous personage, but also by the existence of a high degree of "consumer ethnocentrism' among Chinese consumers (Klein, Ettenson, Krishnan, 2006; Klein, 2002; Liu, Murphy, Li \& Liu, 2007; Orth \& Girbasova, 2003; Wang \& Chen, 2004; Wong, Polonsky \& Garma, 2008). The construct of ethnocentrism describes the tendency of people to reject people who are culturally dissimilar, and at the same time to favor those who are more like themselves. Shimp and Sharma (1987), drawing on studies in the literature of social psychology (Adorno et al., 1950; Tajfel, 1974, 1982), found that consumers tended to favor home-country products even when they did not perceive them as being superior. The long-recognized conceptual rationale for such ethnocentrism is that individuals associate with preferred 'in-groups' while dissociating themselves from and actively rejecting 'outgroups' (Sumner, 1906). Batra et al. (2000) argued that highly ethnocentric consumers can be expected to steer away from buying imported products because such a practice would be regarded as unpatriotic and prejudice domestic jobs, and so on. However, this is not a characteristic that defines the specific consumer group under review. Indeed, consumers from Shanghai city display idiosyncrasies other than those manifested in other areas of China. They are more international, less ethnocentric, and more used to Western customs (Arasanz \& Gu, 2009; Ralston et al., 1996).

The choice of celebrity in terms of the influence of the celebrity's ethnicity on the perceived country of origin of the product or brand

A distinct body of research links the observed influence of the ethnicity of celebrities featured in advertisements on consumer reactions to the perceived country of origin of the product or brand (Chao, Wuhrer \& Werani, 2005). In the present context, it is intuitively logical to assume that brands endorsed by Western celebrities will be seen as of foreign origin by Chinese consumers, and vice versa. In this sense, the ethnicity of the celebrity used as a brand endorser in advertising will have the power to influence consumer perceptions about the brand and the quality of the product through the effect that the ethnic origin of the personality produces regarding the perceived country of origin of the product or brand.

Country of origin (COO) was defined by Roth and Romeo (1992: 480) as "the overall perception consumers form of products from a particular country, based on their prior perceptions of the country's production and marketing strengths and weaknesses". Accordingly, consumers often arrive at the belief that French wine, Italian leather, German beer, and Japanese electronics are the "best". The tendency is to rate products from industrialized countries more favorably than those from less developed countries. In this regard, the country category is what basically determines product assessments (Zhou, Murray \& Zhang, 2002).
Numerous studies have found that COO (Schooler, 1965) has an effect on: attitudes to a product or brand (Lee \& Ganesh, 1999; Papadopoulos et al., 1987; Papadopoulos, Heslop \& Beracs, 1990; Teas \& Agarwal, 2000); evaluation of its attributes and quality (Ahmed et al., 2002; Kaynak, Kucukemiroglu \& Hyder, 2000); perception of its value (Teas \& Agarwal, 2000); preference for one brand over another (Keown \& Casey, 1995; Kim \& Pysarchik, 2000); and purchase intentions (Ahmed \& d'Astous, 1995; Han, 1989; Lin \& Sternquist, 1994; Maher \& Carter, 2011; Wang \& Yang, 2008; Zhang, 1996).

According to the literature, the influence of COO may also vary within a single territory, and can be positive or negative depending on the product (Brucks \& Zeithaml, 1991; D’Astous \& Ahmed, 1992). In China, foreign automotive and cosmetics brands are seen to be of better quality than their Chinese counterparts, and have a stronger reputation. For such products, brands perceived as having a non-local country of origin, especially from the West, are attitudinally preferred to brands seen as local, for reasons not only of perceived quality but also of social status (Batra et al., 2000) and of the consumer need for uniqueness (Liang \& He, 2012). This is especially true at the luxury end of the market, where a Western image connotes success/status, cosmopolitanism and modernity (Cheon, Kin \& Zheng, 2010; Zhou \& Belk, 2004). In practice, the social distinction of the brand can outweigh the utilitarian value of the product, and is a crucial determinant of purchase decisions (Zhou \& Hui, 2003). Status display of this kind has great weight in developing countries such as China, where interpersonal relationships are of primordial importance $(\mathrm{Ge}$, Belk \& Lasco et al., 1993: 105) and where, because of the economic transition, income disparities and status mobility are marked (Batra et al., 2000).

On the other hand, local brands enjoy a higher market share and a better image than their foreign competitors in sectors dealing with white goods, non-alcoholic beverages such as tea and water, domestic appliances, telecommunications, and computers (Delong et al., 2004; Verlegh \& Steenkamp, 1999; Wang \& Yang, 2008; J. Wang, 2006; Zhou \& Belk, 2004). The strategic choice between a local or foreign 'face' thus depends critically on the class of product concerned.

A study by Zhou and Belk (2004) identified two reactions to global and local television and print advertising by Chinese consumers. One largely reflected a drive to achieve cosmopolitanism and status through the consumption of global goods, for the sake of mianzi, which Wong and Ahuvia (1998) define as the personal prestige that an individual seeks to communicate to others. The other reaction found in the same study reflected a more local focus on Chinese values. The authors concluded that the widespread drive among their participants to achieve mianzi via fashion and beauty products associated with the West needs to be balanced against the countervailing desire to forge and reinforce a distinctly Chinese identity in a changing world by choosing Chinese products, demonstrated in other studies by Cui (1997), Wan (2001a, 2001b), Wang, Z. (2001), Wu (2001), Zelinsky (2001) and 
Zhang (2001). This is particularly true for such non-luxury, non-cosmopolitan, distinctively local goods as Chinese medicines, foods and non-alcoholic beverages, or banking and financial services. While these product categories develop and evolve in China just as elsewhere, they are seen as elements of the buyer's identity and not merely as consumer goods subject to superficial fashions (Eves \& Cheng, 2007; Farquhar, 2002; Jing, 2000; Wu \& Tan, 2001). Many companies in those sectors seek to arouse consumers' ethnocentricity and thereby build emotional links with them (Hong \& Schweitzer, 1996). Chinese consumers can thus find themselves facing a conflict between ethnocentrism and ostentatious or conspicuous consumption, where the latter often wins out (Wang \& Chen, 2004; Podoshe, Li \& Zhang, 2011).

\section{The distinguishing characteristics of Chinese consumers from the cosmopolitan city of Shanghai}

In the Chinese market two realities exist side by side: the market in the rural areas, which represents 70 percent of the total; and an urban market, with differences between large and medium-sized cities, comprised of just over 400 million individuals. In big cities such as Beijing, Shanghai, Guang Zhou and Hong Kong we find consumer profiles similar to those in the Western markets, which encompass the global consumer. According to Ralston et al. (1996), Chinese consumers in Shanghai are identified by specific idiosyncrasies that distinguish them from those who live in other areas of China. They are more international, less ethnocentric, more open and accustomed to Western customs, and display significantly higher levels of individualism, openness-to-change, and self-enhancement than do Chinese consumers from other areas such as Dalian, Chengdu or Lanzhou.

The waves of immigrants and of new foreign companies that have reached Shanghai seem to have galvanized a new culture that today blurs the frontier between East and West. Chinese consumers in Shanghai are used to seeing countless advertising messages produced both by local and foreign companies that interchangeably utilize local and foreign celebrities in their ads. Furthermore, as researchers O'Cass and Lim point out (2002), the fact that bilingual brand names (brand names in Mandarin and English at the same time) are employed by local and foreign companies in Shanghai city is leading to great confusion among consumers as to what the countries of origin of different brands are, so that they sometimes perceive a local brand to be foreign, and vice versa. At the same time, the exposure of consumers to advertisements for foreign brands using local celebrities (Yao Ming for brands such as Reebok, Apple and Coca Cola, Ziyi Zhang for the brands Omega and Swarovski, Andy Lau for Acura, Jackie Chan for Canon, etc.), as well as to brand ads from local companies that increasingly employ foreign celebrities (David Beckham or Pierce Brosnan for some Chinese medicinal product brands, Cindy Crawford or Elizabeth Hurley for local beauty product brands, etc.), spread even more confusion among Chinese consumers as to the origin of different brands (Zhou
\& Meng, 1998; Hooper, 2000; Zhang, 2001; Zhou \& Hui, 2003; Zhou, Hui \& Zhou, 2007; Zhuang et al., 2008). In consequence, the ethnic origin alone of the celebrity in question, does not act as an indicator of the brand's country of origin (Sharma \& Spencer, 2010). The ethnicity of celebrities associated with the brand does not in itself affect perceptions of the national origin of the advertised brand in the cosmopolitan city of Shanghai. Thus, the lack of any significant effect of the ethnicity of celebrities on the perceived country of origin of a brand precludes country image having any effect on either attitudes to brand, or perceptions of product quality.

Therefore, we establish the following hypotheses for our research:

H1: The ethnic identity of celebrities used as brand endorsers in advertising does not influence the way in which the country of origin of the advertised brand is perceived for the specific case of cosmopolitan Shanghai consumers.

H2: The ethnic identity of celebrities used as brand endorsers in advertising (through its effect on the perceived country of origin) does not influence attitudes towards the brand for the specific case of cosmopolitan Shanghai consumers.

H3: The ethnic identity of celebrities used as brand endorsers in advertising (through its effect on the perceived country of origin) does not influence perceived product quality for the specific case of cosmopolitan Shanghai consumers.

\section{Method}

Data for analysis were collected in personal interviews with a sample of 797 consumers (353 male; 444 female) aged between 14 and 53, in the city of Shanghai. Respondents were selected by the street intercept method of list-free systematic random sampling. Each respondent was exposed to one of a selection of 24 purpose-designed print advertisements, half of which were for a fashion wristwatch and half for a non-alcoholic beverage (a mineral water brand). The advertised products were chosen to contrast a fashion item, which could support the owner's drive to achieve mianzi, with an everyday product of domestic origin. In each of the two selections of twelve treatments, six were endorsed by one of six Chinese celebrities and six by one of six Western celebrities. The stimulus ads, in their entirety, were chosen on the basis of focus groups. The designs and bilingual brand name remained constant. The layout, also constant, combined a photographic image of just the endorser's face, occupying the left-hand two thirds of the display area; a product shot and the bilingual versions of the brand occupied the remaining third. In short, the advertising message was not 'contextualized' by explicit connections between the endorser and the product, made through direct visual or verbal associations: the endorser 
was not wearing the watch or holding the mineral water bottle, and no statement of endorsement was made.

A recent study comparing Chinese and American advertisements (Liang, Runyan \& Fu, 2011) has found that 'contextualized' creative treatments, in which such associations do exist, are more common in Chinese than American advertising, reflecting the two cultures' respective tendency to a context-dependent and context-independent mode of thinking. In other words, the test advertisements were somewhat 'American', even when the endorsers were Chinese. Given that the study in question is the only one so far to have examined this style contrast in the context of advertising communication, and that the observed effects were moderated by product class, product category and magazine category (and "may" also have been moderated by involvement), this accidental choice of a non-contextualized style is not a methodological issue at present. Appendix 1 presents paired advertisements featuring four of the twelve endorsers.

The fictitious brand name applied to both products was chosen on the basis of focus group discussions with a total of 92 students in the School of Business of a major university in Shanghai: 60 female and 32 male, aged between 18 and 29. The English version, Premis, is neutral, in the sense that it has no direct meaning or connotation in China. The transliteration in Chinese was simply a phonetic rendition, which likewise had no meaning that could convey either positive or negative brand associations: a methodological strategy previously adopted by Hong et al. (2002) and Chan \& Huang (2001).

The choice of endorsers was the result of a process in which the same focus group participants named their ten favorite Chinese and ten favorite Western celebrities: five male and five female in each case. The resulting pool of names was reduced to a shortlist of those mentioned most frequently, from which six Chinese and six Westerners were arbitrarily chosen, evenly split between male and female. The representatives of the West were the Hollywood actors Brad Pitt, Tom Cruise, Tom Hanks, Angelina Jolie, Nicole Kidman and Julia Roberts. The ethnically-Chinese male endorsers were all born in Hong Kong before its return to the People's Republic. They are: Jackie Chan, action film actor and choreographer, stunt performer, comedian, and film director; Andy Lau, 'cantopop' singer and film actor and producer; and Tony Leung, the action choreographer and stuntman. Two of their female counterparts are both mainland Chinese film actresses: Li Gong and Zhang Ziyi. The third is Maggie Cheung, an actress born in Hong Kong and raised in England.

The scales measuring the independent variables were derived from the literature review, with the aim of ensuring content validity. For attitude to the brand, the review yielded two dominant bipolar items: good/bad and like/dislike (Cox \& Cox, 1988; Curlo \& Ducoffe, 1998; Kempf \& Smith, 1998). The latter was chosen, in the form of a 7-point semantic differential scale anchored at "I don't like it at all" and "I like it a lot". A reduced version of Shimp and
Sharma's (1987) CETSCALE was utilized to measure consumer ethnocentrism. This scale has previously been used and validated in various cross-cultural contexts, including in Central and Eastern Europe (e.g., Ettenson \& Klein, 2005; Nijssen \& Douglas, 2004; Reardon et al., 2005; Russell \& Russell, 2006; Steenkamp \& Baumgartner, 1998). Respondents were asked about their level of agreement according to a 7-point scale ranging from 1, strongly disagree, to 7, strongly agree, with each of the following statements: 'I always prefer domestic products/brands', 'Foreign products should not be purchased because this harms the domestic economy and causes unemployment', and 'Foreign products/brands should be purchased only when no domestic alternatives are available'. Cronbach's alpha for the scale was 0,7 . Perceived product quality was established as a one-dimensional construct and measured by a 7-point semantic differential scale anchored at "The quality of this product is very poor ... excellent" (Klein, Ettenson \& Morris, 1998). Lastly, the perceived country of origin of the brand was measured by asking respondents to name it as either "local or Chinese" or "foreign", following the lead of Insch and McBride (2004) and Kaynak et al. (2000).

\section{Results}

The influence of the ethnic identity of the celebrities on the perceived country of origin of the brand (H1) was tested by Pearson's Chi-Square statistic. Table 1 shows that there is no significant link between the two variables, and it can therefore be deduced that the ethnicity of celebrities associated with the brand does not in itself affect perceptions of the national origin of the advertised brand for the specific case of cosmopolitan Shanghai consumers. The results thus support Hypothesis 1.

Table 1: Cross tabulation analysis of the influence of celebrity endorsers' ethnicity on perceived country of origin

\begin{tabular}{|c|c|c|c|c|c|c|}
\hline \multirow{5}{*}{ Ethnicity } & \multirow{4}{*}{$\begin{array}{l}\text { Western } \\
\text { Chinese }\end{array}$} & \multicolumn{2}{|c|}{$\begin{array}{c}\text { Brand } \\
\text { perceived as } \\
\text { local }\end{array}$} & \multicolumn{2}{|c|}{$\begin{array}{c}\text { Brand } \\
\text { perceived as } \\
\text { foreign }\end{array}$} & \multirow[t]{2}{*}{ Total } \\
\hline & & $\mathrm{n}$ & $\%$ & $\mathrm{n}$ & $\%$ & \\
\hline & & 181 & 48,5 & 202 & 49,3 & 383 \\
\hline & & 192 & 51,5 & 208 & 50,7 & 400 \\
\hline & Total & 373 & & 410 & & 783 \\
\hline
\end{tabular}

Notes: Pearson's Chi-Square $=0,04 ; \mathrm{p}=0,84$

The results of ANOVA testing of the scaled data relating to Hypotheses 2 and 3, presented in Table 2, show that there are no significant differences between the mean scores obtained in the different versions of the advertisement for the two variables analyzed: attitude to the brand $(\mathrm{H} 2)$ and perceived product quality (H3). These results thus support Hypotheses 2 and 3 . So, the finding is clearly that the ethnicity of celebrities used as implicit brand endorsers does not influence either attitudes to the brand, or perceptions of product quality for the specific case of cosmopolitan Shanghai consumers. The lack of any significant effect of the ethnicity of celebrities on the perceived country of origin 
of a brand (H1) precludes country image having any effect on those variables in the world-wide Chinese consumer. This lack of any discernible differential effect applies whether the advertised brand is a fashion product appealing to Chinese consumers' sense of mianzi, in this case a wristwatch, or a convenience product such as mineral water.

\section{Table 2: ANOVA analysis of mean values differences between experimental groups (Chinese Celebrity - Western} celebrity).

\begin{tabular}{|c|c|c|c|c|c|c|c|}
\hline $\begin{array}{l}\text { Dependent } \\
\text { variable }\end{array}$ & Product Type & $\begin{array}{l}\text { Experimental } \\
\text { factor }\end{array}$ & $\mathrm{N}$ & Mean & Std. Deviation & $\mathrm{F}$ & $\mathrm{p}$ \\
\hline \multirow[t]{4}{*}{$\mathrm{ABr}$} & \multirow[t]{2}{*}{$\mathrm{F}$} & Chinese C. & 203 & 3,24 & 1,30 & \multirow[t]{2}{*}{0,088} & \multirow[t]{2}{*}{0,77} \\
\hline & & Western C. & 192 & 3,28 & 1,38 & & \\
\hline & \multirow[t]{2}{*}{$\mathrm{C}$} & Chinese C. & 204 & 3,46 & 1,43 & \multirow{2}{*}{0,002} & \multirow{2}{*}{1,00} \\
\hline & & Western C. & 198 & 3,45 & 1,38 & & \\
\hline \multirow{4}{*}{$\begin{array}{l}\text { Product } \\
\text { quality }\end{array}$} & $\mathrm{F}$ & Chinese C. & 203 & 4,08 & 1,40 & \multirow{2}{*}{0,021} & \multirow{2}{*}{0,89} \\
\hline & \multirow{3}{*}{$\mathrm{C}$} & Western C. & 192 & 4,06 & 1,50 & & \\
\hline & & Chinese C. & 204 & 4,16 & 1,54 & \multirow{2}{*}{0,117} & \multirow{2}{*}{0,73} \\
\hline & & Western C. & 198 & 4,11 & 1,41 & & \\
\hline
\end{tabular}

Notes: ABr: Attitude toward the brand; F: Fashion product; C: Convenience product

\section{Conclusions and implications}

In conclusion, the current study highlights that there is no statistically significant relationship between the ethnic origin of celebrities featured in advertising in cosmopolitan China (Shanghai) and the perceived country of origin of the brands endorsed. These results are obtained for the case of two examples of a fashion and convenience product in a large and historically 'westernized' Chinese city, which is known to have sustained a higher rate of economic growth than the rest of the country and to be more open to the outside world (Davis, 2000). The implication for international marketers targeting this cosmopolitan Chinese market is clearly that neither the perceived ethnicity of celebrities associated with the brand nor the national image of its country of origin is an important enough factor in the effectiveness of an advertising campaign to demand a disproportionate amount of time and effort in strategic campaign planning.

Our finding is supported by a recent published report from the multinational marketing research agency Millward Brown (Sharma \& Spencer, 2010). It found that celebrity endorsement campaigns constituted 32 per cent of a multinational sample of consumer advertising, versus 19 per cent in the rest of Asia and nine per cent globally, and also that certain celebrities were multiple endorsers. Greatly exceeding Yao Ming's portfolio of six, for example, the Taiwanese actress and singer Jolin Tsai was at the time promoting 14 multinational brands including McDonald's and Levi's. The net result is, according to the report, "a marketplace so flooded with familiar faces that, at the end of the day, leaves consumers unable to recall which brand is endorsed by which celebrity". There is ample evidence from other studies to support the conclusion that this situation confuses Chinese consumers about the actual origin of the brands in question (Hooper, 2000; Zhang, 2001; Zhou \& Hui, 2003; Zhou \& Meng, 1998; Zhou et al., 2007; Zhuang et al., 2008; O'Cass \& Lim, 2002). Thus, the usual strategy of using bilingual brand names (in English and Chinese) by both foreign and local companies likewise tends to spread confusion among Chinese consumers regarding the country of origin of the different brands in the market (Zhang \& Schmitt, 2001, 2004). Zhuang et al. (2008), attributing a detectable decline in the competitiveness of foreign brands in China to such confusion about the origin of a brand, found an "asymmetric effect" in a study of 67 local and foreign brands among 400 university students in China. Domestic brands enjoyed an advantage as long as a high level of confusion was present, but that effect diminished as consumer knowledge of the origin improved.

The results of our own study may also be explained by the low level of consumer ethnocentrism among the consumers in the sample. Mean scores on the seven-point Likert scales used to measure this attribute were all below the mid-point, with the overall average standing at 2.98. It seems that Chinese consumers from Shanghai city are indeed more open, less ethnocentric and more global than their fellow citizens in other areas of China, so the foreignness of celebrities featured in the advertising causes no prejudice against the product, whether it is an international fashion item or a domestic mainstream product.

Given that the ethnicity of celebrities in itself is no longer a reliable indicator of the country of origin of a brand in cosmopolitan China, a logical ingredient of future marketing communications would be an explicit 'made in' element. In that way, the link between the perceived origin of a brand and the audience's responses to it could be re-established. For the moment, however, our study strongly suggests that, for contemporary urban Chinese consumers, the fact of celebrity transcends the effect of ethnicity.

\section{References}

Adorno, T. W., Frenkel-Brunswik, E., Levinson, D. \& Sanford, R. N. 1950. The authoritarian personality. New York, NY: Harper \& Row.

Ahmed, S. A. \& D'Astous, A. 1995. 'Comparison of country-of-origin effects on household and organizational 
buyers' product perceptions', European Journal of Marketing, 29(3): 35-51.

Ahmed, Z. U., Johnson, J. P., Ling, C. P., Fang, T. W. \& Hui, A. K. 2002. 'Country-of-origin and brand effects on consumers: Evaluations of cruise lines', International Marketing Review, 19(3): 279-302.

Alden, D. L., Steenkamp, J. \& Batra, R. 1999. 'Brand positioning through advertising in Asia, North America and Europe: The role of global consumer culture', Journal of Marketing, 63(1): 75-87.

Arasanz, L. \& Gu, Y. 2009. Vender en China (in Spanish). Barcelona, Spain: Viena Ediciones.

Atkin, C. \& Block, M. 1983. 'Effectiveness of celebrity endorsers', Journal of Advertising Research, 1(1): 57-61.

Batra, R., Ramaswamy, V., Alden, D. L., Steenkamp, J. \& Ramachander, S. 2000. 'Effects of brand local and nonlocal origin on consumer attitudes in developing countries', Journal of Consumer Psychology, 9(2): 83-95.

Baughn, C. C. \& Yaprak, A. 1993. 'Mapping country-oforigin research: Recent developments and emerging avenues.' In Papadopoulas, N. \& Heslop, L. (eds.). Productcountry images: Impact and role in intemational marketing. New York: Intemational Business Press (Haworth), pp. 89116.

Bilkey, W. J. \& Nes, E. 1982. 'Country-of-origin effects on product evaluations', Journal of International Business Studies, 13(1): 89-99.

Brucks, M. \& Zeithaml, V. A. 1991. 'Price and brand name as indicators of quality dimensions. Marketing Science Institute Working Paper, Report Number 91-130, Cambridge, MA.

Bush, A. J., Martin, C. A. \& Bush, V. D. 2004. 'Sports celebrity influence on the behavioral intentions of Generation Y', Journal of Advertising Research, 44(1): 108119.

Chan, A. K. K. \& Huang, Y-Y. 2001. 'Chinese brand naming: A linguistic analysis of the brands of ten product categories', Journal of Product and Brand Management, 10(2): 103-119.

Chan, K. \& Zhang, C. 2007. 'Living in a celebrity-mediated social world: The Chinese experience', Young Consumers: Insight and Ideas for Responsible Marketers, 8(2): 139-152.

Chao, P., Wuhrer, G. \& Werani, T. 2005. 'Celebrity and foreign brand name as moderators of country-of-origin effects', International Journal of Advertising, 24(2): 173192.

Chattaraman, V., Lennon, S. J. \& Rudd, N. A. 2010. 'Social identity salience: Effects of identity based-brand choices of
Hispanic consumers', Psychological \& Marketing, 27(3): 263-284.

Cheong, Y., Kim, K. \& Zheng, L. 2010. 'Advertising appeals as a reflection of culture: A cross-cultural analysis of food advertising appeals in China and the US', Asian Journal of Communication, 20(1): 1-16.

Cheong, Y., Zheng, L. \& Kim, K. 2011. 'Product global reach, advertising standardization, and cultural values: An analysis of 2008 Beijing Olympic TV commercials', Asian Journal of Communication, 21(3): 279-300.

Cox, D. S. \& Cox, A. D. 1988. 'What does familiarity breed? Complexity as a moderator of repetition effects in advertising evaluation', Journal of Consumer Research, 15: 111-116.

Cui, G. 1997. 'The name game: Foreign and PRC brands race to build their reputation and market shares in China', China Business Review, 24(6): 40-43.

Cui, G. \& Yang, X. 2009. 'Responses of Chinese consumers to sex appeals in international advertising: A test of congruency theory', Journal of Global Marketing, 22(3): 229-245.

Curlo, E. \& Ducoffe, R. 1998. 'Product use goals and attitudinal responses to ads', Journal of Current Issues of Research in Advertising, 20(1): 19-32.

D’Astous, A. \& Ahmed, S. A. 1992. 'Multi-cue evaluation of made-in concept: A conjoint analysis study in Belgium', Journal of Euromarketing, 2(1): 9-29.

Davis, D. S. 2000. The consumer revolution in urban China. Berkeley, CA: University of California Press.

Delong, M., Bao, M., Wu, J., Chao, H. \& Li, M. 2004. 'Perception of US branded apparel in Shanghai', Journal of Fashion Marketing and Management, 8(2): 141-153.

DeShields, O. W. Jr., Kara, A. \& De Los Santos, G. 1999. 'A comparison of spokesperson homophily and credibility on the effectiveness of the advertisement.' In Gordon, P.J. \& Kellerman, B.J. Proceedings of the 1999 American Marketing Association Sumer Educators Conference 7-10 August 1999, Volume 10. San Francisco, CA.

Ettenson, R \& Klein, J.G. 2005 'The fallout from French nuclear testing in the South Pacific', International Marketing Review, 22(2): 199-224.

Eves, A. \& Cheng, L. 2007. 'Cross-cultural evaluation of factors driving intention to purchase new food products Beijing, China and south-east England', International Journal of onsumer Studies, 31(4): 410-417.

Farquhar, J. 2002. Appetites: Food and sex in post-socialist China. Durham, NC: Duke University Press. 
Frieden, J. B. 1984. 'Advertising spokesperson effects: An examination of endorser type and gender on two audiences', Journal of Advertising Research, 24(5): 33-41.

Friedman, H. H. \& Friedman, L. 1979. 'Endorser effectiveness by product type', Journal of Advertising Research, 19(5): 63-71.

Frith, K. T., Cheng, H. \& Shaw, P. 2004. 'Race and beauty: A comparison of Asian and Western models in women's magazine advertisements', Sex Roles, 50(1/2): 53-61.

Gan, W. 2006. 'Effectiveness of celebrity endorsement advertising in Chinese marketplace.' Unpublished dissertation, University of Nottingham, Nottingham, UK. [online]URL:http://edissertations.nottingham.ac.uk/225/1/06 MAlixwg1.pdf.

Ger, G., Belk, R. W. \& Lascu, D. N. 1993. 'The development of consumer desire in marketing and developing economies: The cases of Romania and Turkey'. In McAlister, L. \& Rothschild, M.L. (eds.). Advances in consumer research 20:102-107.: Association for Consumer Research.

Glenn, E. S., Witmeyer, D. \& Stevenson, K. A. 1977. 'Cultural styles of persuasion', International Journal of Intercultural Relations, 1(3): 52-66.

Goldsmith, R. E., Lafferty, B. A. \& Newell, S. J. 2000. 'The impact of corporate credibility and celebrity credibility on consumer reaction to advertisements and brands', Journal of Advertising, 29(3): 43-54.

Han, M. C. 1989. 'Country image: halo or summary construct?' Journal of Marketing Research, 26(2): 222-229.

Holt, D. B., Quelch, J. A. \& Taylor, E. L. 2004. 'How global brands compete', Harvard Business Review, 82(9): 68-75.

Hong, C. Y. 1994. 'Reflections of cultural values: A content analysis of Chinese magazine advertisements from 1982 and 1992', International Journal of Advertising, 13(2): 167-183.

Hong, C. Y. \& Schweitzer, J. C. 1996. 'Cultural values reflected in Chinese and US television commercials', Journal of Advertising Research, 36(3): 27-45.

Hong, F. C., Pecotich, A. \& Shultz, C. J. II. 2002. 'Brand name translation: language constraints, product attributes, and consumer perceptions in East and Southeast Asia', Journal of International Marketing, 10(2): 29-45.

Hooper, B. 2000. 'Globalization and resistance in post-Mao China: The case of foreign consumer products', Asian Studies Review, 24(4): 439-470.

Insch, G. S. \& McBride, J. B. 2004. 'The impact of countryof-origin cues on consumer perceptions of product quality:
A binational test of the decomposed country-of-origin construct', Journal of Business Research, 57(3): 256-265. Jing, J. 2000. Feeding China's little emperors: Food, children and social change. Stanford: Stanford University Press.

Kahle, L. R. \& Homer, P. M. 1985, 'Physical attractiveness of the celebrity endorser: A social adaptation perspective', Journal of Consumer Research, 11: 954-961.

Kamins, M. A. 1990. 'An investigation into the 'match-up' hypothesis in celebrity advertising: When beauty may be only skin deep', Journal of Advertising, 19(1): 4-13.

Kaynak, E., Kucukemiroglu, O. \& Hyder, A. S. 2000. 'Consumers' country-of-origin (COO) perceptions of imported products in a homogenous less-developed country', European Journal of Marketing, 34(9/10): 12211241.

Kempf, D. S. \& Smith, R. E. 1998. 'Consumer processing of product trial and the influence of prior advertising: A structural modelling approach', Journal of Marketing Research, 35: 325-338.

Keown, C. \& Casey, M. 1995. 'Purchasing behaviour in the Northern Ireland wine market', British Food Journal, 97(1): $17-20$.

Kim, S. \& Pysarchik, D. T. 2000. 'Predicting purchase intentions for uni-national and bi-national products', International Journal of Retail and Distribution Management, 28(6): 280-291.

Klein, J. G. 2002. 'Us versus them or us versus everyone? Delineating consumer aversion to foreign goods', Journal of International Business Studies, 33(2): 345-363.

Klein, J. G., Ettenson, R. \& Krishnan, B. C. 2006. Extending the construct of consumer ethnocentrism: When foreign products are preferred', International Marketing Review, 23(3): 304-321.

Klein, J. G., Ettenson, R. \& Morris, M. 1998. 'The animosity model of foreign product purchase: An empirical test in the People's Republic of China', Journal of Marketing, 62(1): 89-100.

Leach, M. P. \& Liu, A. H. 1998. 'The use of culturally relevant stimuli in international advertising', Psychology \& Marketing, 15(6): 523-546.

Lee, D. \& Ganesh, G. 1999. 'Effects of partitioned country image in the context of brand image and familiarity', International Marketing Review, 16(1): 18-39.

Liang, B. \& He, Y. 2012. 'The effect of culture on consumer choice: The need for conformity vs. the need for uniqueness', International Journal of Consumer Studies, 36(3): 352-359. 
Liang, B., Runyan, R. C. \& Fu, W. 2011. 'The effect of culture on the context of ad pictures and ad persuasion: The role of context-dependent and context-independent thinking', International Marketing Review, 28(4): 412-434.

Lin, L. \& Sternquist, B. 1994. 'Taiwanese consumers' perceptions of product information cues: Country of origin and store prestige', European Journal of Marketing, 27(12): 5-18.

Liu, F., Murphy, J., Li, J. \& Liu, X. 2007. 'English and Chinese? The role of consumer ethnocentrism and country of origin in Chinese attitudes towards store signs', Australasian Marketing Journal, 14(2): 5-16.

Liu, M. T., Huang, Y-Y. \& Minghua, J. 2007. 'Relations among attractiveness of endorsers, match-up, and purchase intention in sport marketing in China', Journal of Consumer Marketing, 24(6): 358-365.

Maher, A. A. \& Carter, L. L. 2011. 'The affective and cognitive components of country image: Perceptions of American products in Kuwait', International Marketing Review, 28(6): 559-580.

McCracken, G. 1989. 'Who is the celebrity endorser? Cultural foundations of the endorsement process', Journal of Consumer Research, 16: 310-321.

Morimoto, M. \& La Ferle, C. 2008. 'Examining the influence of culture on perceived source credibility of Asian Americans and the mediating role of similarity', Journal of Current Issues and Research in Advertising, 30(1): 49-60.

Newcomb, T. M. 1968. 'Interpersonal balance'. In Abelson, R.P. et al. (eds.). Theory of cognitive consistency - a sourcebook. Chicago IL.: Rand McNally, pp. 10-51.

Nijssen, E. J. \& Douglas, S. P. 2004. 'Examining the animosity model in a country with a high level of foreign trade', International Journal of Research in Marketing, 21(1): 23-38.

O'Cass, A. \& Lim, K. 2002. 'Understanding the younger Singaporean consumers' views of Western and Eastern brands', Asia Pacific Journal of Marketing and Logistics, 14(4): 54-79.

Orth, U. R. \& Girbasova, Z. 2003. 'The role of consumer ethnocentrism in food product evaluation', Agribusiness, 19(2): 137-147.

Paek, H. J. 2005. 'Understanding celebrity endorsers in cross-cultural contexts: A content analysis of South Korean and US newspaper advertising', Asian Journal of Communication, 15(2): 133-153.

Papadopoulos, N., Heslop, L. A. \& Beracs, J. 1990. 'National stereotypes and product evaluations in a socialist country', International Marketing Review, 7(1): 32-47.
Papadopoulos, N., Heslop, L. A., Graby, F. \& Avlonitis, G. 1987. 'Does country of origin matter? Some findings from a cross-cultural study of consumer views about foreign products'. Marketing Science Institute, Report No. 87-104, Cambridge, MA.

Podoshen, J. S., Li, L. \& Zhang, J. 2011. 'Materialism and conspicuous consumption in China: A cross-cultural examination', International Journal of Consumer Studies, 35(1): 17-25.

Ralston, D. A., Kai-Cheng, Y., Wang, X., Terpstra, R. H. \& Wei, H. 1996. 'The cosmopolitan Chinese manager: Findings of a study on managerial values across the six regions of China', Journal of International Management, 2: 79-109.

Reardon, J., Miller, C., Vida, I. \& Kim, I. 2005. 'The effects of ethnocentrism and economic development on the formation of brand and ad attitudes in transitional economies', European Journal of Marketing, 39(7/8): 737754.

Roth, M. S. \& Romeo, J. B. 1992. 'Matching product category and country image perceptions: A framework for managing country-of-origin effects', Journal of International Business Studies, 23(3): 447-497.

Rumschisky, A. 2010. 'The value of using famous people in advertising communication: A quantitative analysis of prices of a fashion item'. [online]URL:http://www.incommetrics.com/english/?p=179.

Russell, D. W. \& Russell, C. A. 2006. 'Explicit and implicit catalysts of consumer resistance: The effects of animosity, cultural salience and country-of-origin on subsequent choice', International Journal of Research in Marketing, 23(3): 321-331.

Ryu, G., Park, J. \& Feick, L. 2006. 'The role of product type and country-of-origin in decisions about choice of endorser ethnicity in advertising', Psychology \& Marketing, 23(6): 487-513.

Schooler, R. D. 1965. 'Product bias in central American common market', Journal of Marketing Research, 2(4): 394-397.

Sharma, S. \& Spencer, J. 2010. Middle Kingdom's Celebrities To Be - Faceless People and Unsung Heroes Imperatives for Celebrity Advertising in China. Atticus (WPP Group): Atticus Awards 2010.

Shen, F. \& Guo, Z. S. 2013. 'The last refuge of media persuasion: News use, national pride and political trust in China', Asian Journal of Communication, 23 (2).

Shimp, T. A. \& Sharma, S. 1987.'Consumer ethnocentrism: Construction and validation of the CETSCALE', Journal of Marketing Research, 24: 280-289. 
Simmons L. C. \& Schindler, R. M. 2003. 'Cultural superstitions and the price endings used in Chinese advertising', Journal of International Marketing, 11(2): 101-111.

Solomon, M. R. 2002. Consumer behavior: Buying, having and being. $5^{\text {th }}$ Edition. Englewood Cliffs NJ: Prentice Hall.

Spielman, H. M. 1981. 'The celebrity sell: Making it work', Marketing Times, 28: 13-14.

Stafford, M. R., Stafford, T. F. \& Day, E. 2002. 'A contingency approach: The effects of spokesperson type and service type on service advertising perceptions', Journal of Advertising, 31(2): 17-35.

Steenkamp, J. \& Baumgartner, H. 1998. 'Development and cross-cultural validation of a short form of CSI as a measure of optimum stimulation level', International Journal of Research in Marketing, 12(2): 97-104.

Steenkamp, J., Batra, R. \& Alden, D. L. 2003. 'How perceived brand globalness creates brand value', Journal of International Business Studies, 34(1): 53-65.

Sumner, W. G. 1906. Folkways. New York, NY: Ginn.

Tajfel, H. 1974. 'Social identity and intergroup behaviour', Social Science Information, 13(2): 65-93.

Tajfel, H. 1982. Social identity and intergroup relations. Cambridge, UK: Cambridge University Press.

Teas, R. K. \& Agarwal, S. 2000. 'The effects of extrinsic product cues on consumers' perceptions of quality, sacrifice, and value', Journal of the Academy of Marketing Science, 28(2): 278-290.

The Economist. 2012 'Insulting advertisements. Ad hominem'. 31 December 2011 - 6 January 2012: 47.

Venkatesh, A. \& Swamy, S. 1994. 'India as an emerging consumer society-A cultural analysis.' In Schultz, C.J.II, Belk, R.W. \& Ger, G. (eds.). Research in consumer behavior. Greenwich, 7:193-223.

Verlegh, P. W. J. \& Steenkamp, J. E. M. 1999. 'A review and meta-analysis of country-of-origin research', Journal of Economic Psychology, 20(5): 521-546.

Wan, L. 2001a. Tactics of thirty-six well-known Chinese brands (in Chinese). Beijing, PRC: Chinese Commerce Publishing House.

Wan, L. 2001b. Strategies of thirty-five well-known Chinese brands (in Chinese). Beijing, PRC: Chinese Commerce Publishing House.

Wang, C. L. \& Chen, Z. X. 2004. 'Consumer ethnocentrism and willingness to buy domestic products in a developing country setting: Testing moderating effects', Journal of Consumer Marketing, 21(6): 391-400.

Wang, C. L., Bristol, T., Mowen, J. C. \& Chakraborty, G. 2000. 'Alternative modes of self-construal: Dimensions of connectedness-separateness and advertising appeals to the cultural and gender-specific self,' Journal of Consumer Psychology, 9(2): 107-115.

Wang, J. 2006. 'The politics of goods: A case study of consumer nationalism and media discourse in contemporary China', Asian Journal of Communication, 16(2): 187-206.

Wang, X. \& Yang, Z. 2008. 'Does country-of-origin matter in the relationship between brand personality and purchase intention in emerging economies? Evidence from China's auto industry', International Marketing Review, 25(4): 458474.

Wang, Z. 2001. Contending for hegemony in China (in Chinese). Guiyang, PRC: Guizhou People's Publishing House.

Wong, C. Y., Polonsky, M. J. \& Garma, R. 2008. 'The impact of consumer ethnocentrism and country of origin sub-components for high involvement products on young Chinese consumers' product assessments', Asia Pacific Journal of Marketing and Logistics, 20(4): 455-478.

Wong, N. Y. \& Ahuvia, A. C. 1998. 'Personal taste and family face: Luxury consumption in Confucian and Western societies', Psychology and Marketing, 15(5): 430-441.

Wu, D. Y. H. \& Tan, C-beng 2001. Changing Chinese foodways in Asia. Hong Kong, PRC: Hong Kong University Press.

Wu, X. 2001. Big failures (in Chinese). Hangzhou, PRC: Zhejiang People's Publishing House.

Zelinsky, W. 2001. 'The world and its identity crisis'. In Adams, P.C., Hoelscher, S. \& Ti, K.E. (eds.). Textures of place: Exploring humanist geographies. Minneapolis, MN: University of Minnesota Press, pp. 129-149.

Zhang, B. 2001. Branding no more? Guangzhou: Guangdong Economy Publishing House.

Zhang, S. \& Schmitt, B. H. 2001. 'Creating local brands in multilingual international markets', Journal of Marketing Research, 38(August): 313-325.

Zhang, S. \& Schmitt, B. H. 2004. 'Activating sound and meaning: The role of language proficiency in bilingual consumer environments', Journal of Consumer Research, 31(1): 220-228.

Zhang, Y. 1996. 'Chinese consumers' evaluation of foreign products: The influence of culture, product types and product presentation format', European Journal of Marketing, 30(12): 50-69. 
Zhang, Y. \& Gelb, B. D. 1996. 'Matching advertising appeals to culture: The influence of products' use conditions', Journal of Advertising, 25(3): 29-46.

Zhou, L. \& Hui, M. 2003. 'Symbolic value of foreign products in the People's Republic of China', Journal of International Marketing, 11(2): 36-48.

Zhou, L., Hui, M. H. \& Zhou, N. 2007. 'Confidence in brand origin and its strategic implications evidence from a developing market', Proceedings of the Annual Conference Administrative Sciences Association of Canada (ASAC), Ottawa, Canada.

Zhou, L., Murray, I. \& Zhang, B. 2002. 'People's perceptions of foreign hotel chains in China's market: An empirical study of the effects of country-of-origin and corporate identity', Journal of Travel \& Tourism Marketing, 11(4): 43-65.

Zhou, N. \& Belk, R. W. 2004. 'Chinese consumer readings of global and local advertising appeals', Journal of Advertising, 33(3): 63-76.

Zhou, N. \& Meng, L. 1998. 'Marketing in an emerging consumer society: Character images in China's consumer magazine advertising'. In Strange, R. (ed.). Management in China: The experience of foreign business. London: Frank Cass, pp. 105-117.

Zhuang, G., Wang, X., Zhou, L. \& Zhou, N. 2008. 'Asymmetric effects of brand origin confusion: Evidence from the emerging market of China', International Marketing Review, 25(4): 441-457.

\section{Appendix}
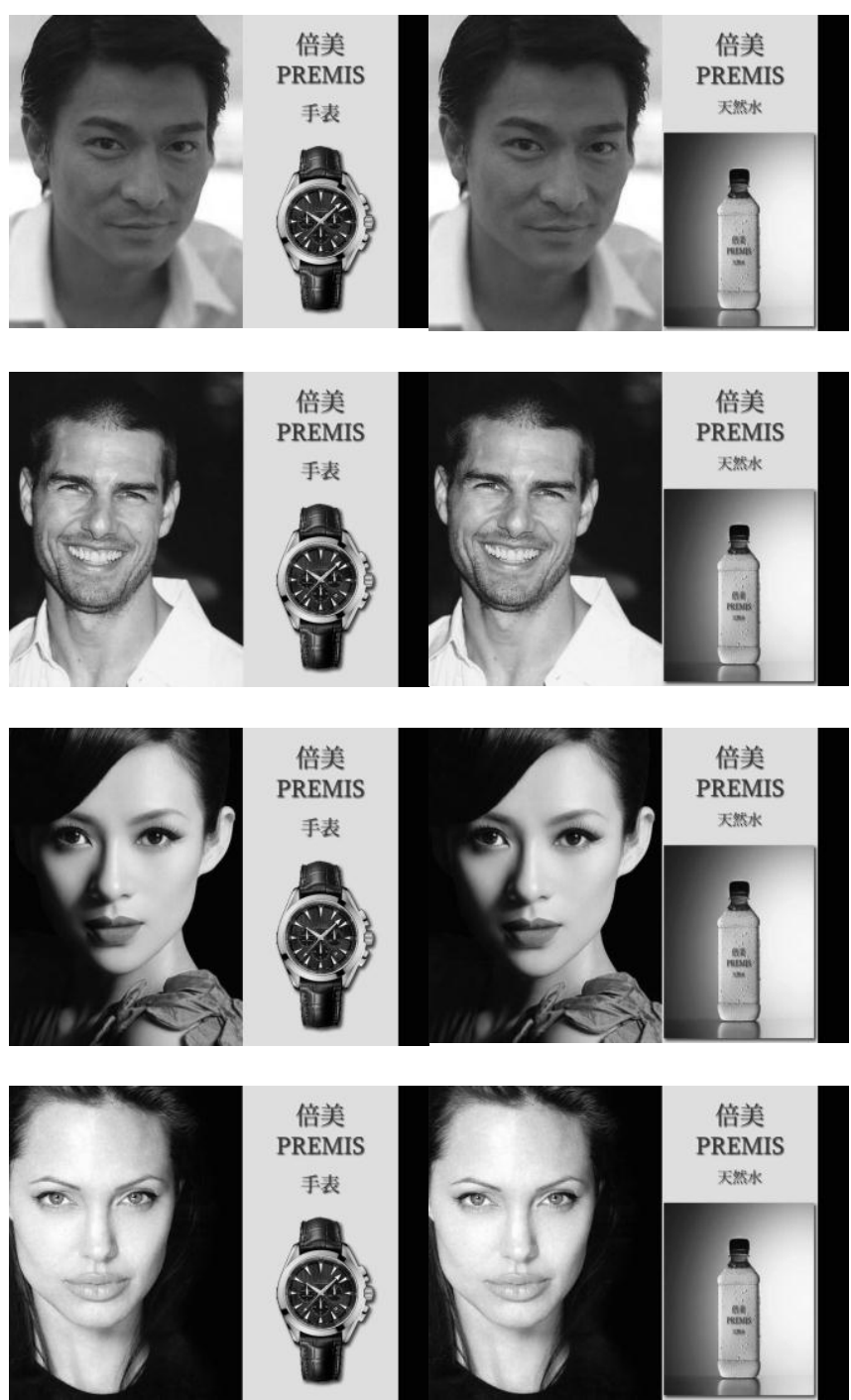